\title{
Analisis faktor-faktor yang berhubungan dengan kadar hemoglobin pada ibu hamil
}

\author{
${ }^{1}$ I G.B. Ngurah Rai \\ ${ }^{2}$ Shirley E. S. Kawengian \\ ${ }^{2}$ Nelly Mayulu
}

\author{
${ }^{1}$ Kandidat Skripsi Fakultas Kedokteran Universitas Sam Ratulangi Manado \\ ${ }^{2}$ Bagian Ilmu Kesehatan Gizi Fakultas Kedokteran Universitas Sam Ratulangi Manado \\ Email: gusti_bagus95@yahoo.com
}

\begin{abstract}
Abstrak: Anemia merupakan suatu kondisi di mana jumlah dan ukuran sel darah merah, atau konsentrasi hemoglobin di bawah batas nilai normal, akibatnya dapat merusak kapasitas darah untuk mengangkut oksigen yang di hantarkan ke seluruh tubuh. Ibu hamil merupakan salah satu kelompok yang berisiko mengalami anemia karena peningkatan volume plasma yang berakibat pengenceran kadar hemoglobin $(\mathrm{hb})$ tanpa perubahan bentuk sel darah merah. Ibu hamil dianggap mengalami anemia bila kadar Hb-nya $<11,0 \mathrm{~g} / \mathrm{dL}$. Anemia dapat memperburuk proses kelahiran.. Penelitian ini bertujuan untuk melihat apakah ada hubungan antara status pekerjaan, pendidikan dan penghasilan suami dengan kadar hemoglobin. Pengambilan data dilakukan dengan menggunakan metode cross-sectional. Penelitian ini dilakukan pada bulan September-November 2016 di Puskesmas Bahu, Ranotana, Tuminting, Kombos dan Paniki. Pengambilan sampel menggunakan metode total sampling dengan jumlah responden sebanyak 49 orang. Dari hasil penelitian diperoleh nilai p masing-masing sebesar 0,362 status pekerjaan dengan kadar hb, 0,688 pendidikan dengan kadar hb dan 0,650 penghasilan suami dengan kadar hb yakni lebih besar dibanddingkan angka $\alpha=0,05$. Kesimpulan: Tidak ada hubungan antara kadar hemoglobin $(\mathrm{hb})$ dengan status pekerjaan, pendidikan dan penghasilan suami.
\end{abstract}

Kata kunci: kadar hemoglobin, anemia, ibu hamil.

\begin{abstract}
Anemia is a condition which the number and size of red blood cells or the hemoglobin concentration below the normal value, that can damage the capacity of the blood to transport oxygen throughout the body. Pregnant women is one of the groups at risk of anemia. high risk cause of increased plasma volume resulting in hemoglobin dilution without change in shape of the red blood cells. Pregnant women considered to have anemia when hemoglobin concentrate counted below $11.0 \mathrm{~g} / \mathrm{dL}$ and can worsen of giving birth progress. This study aims to determine whether there is a relation between employment status, education, and the husband's income with the hemoglobin level in pregnant women. The study design used cross-sectional research by total sampling method to 49 people during september-november 2016 in Bahu, Ranotana, Tuminting, Kombos, and Paniki public health center. Result of research acquired the p-value of 0.362 , respectively the status of the job with hemoglobin rate 0.688 , education level and hemoglobin rate 0.650 , the husband's income level with hemoglobin rate is bigger than the $\alpha=0.05$. Conclusion: There is no relation between the level of hemoglobin with employment status, education and husband's income.
\end{abstract}

Keywords: hemoglobin, anemia, pregnancy woman 
merupakan masalah gizi mikro terbesar dan tersulit diatasi diseluruh dunia. ${ }^{1}$ Anemia pada kehamilan merupakan masalah kesehatan masyarakat yang utama, di mana estimasi bahwa $41,8 \%$ wanita hamil di seluruh dunia mengalami anemia. Menurut WHO, $40 \%$ kematian Ibu di negara berkembang berkaitan dengan anemia pada kehamilan. Kebanyakan anemia dapat disebabkan oleh defisiensi besi dan perdarahan akut. Kurang lebih 10\% - 20\% ibu hamil didunia menderita anemia pada kehamilannya. Prevalensi anemia pada ibu hamil di dunia berkisar 34\% dimana sekitar $75 \%$ anemia pada ibu hamil berada di Negara berkembang. ${ }^{2}$

Menurut data Riskesdas 21,7\% masalah gizi seperti kurangnya pemenuhan asupan nutrisi di Negara berkembang masih merupakan masalah kesehatan masayarakat. Masalah gizi merupakan penyebab kematian anak secara tidak langsung masih dapat dicegah. Rendahnya statu gizi ibu hamil selama kehamilan dapat mengakibatkan berbagai dampak tidak baik bagi ibu dan bayi, diantaranya yaitu bayi lahir dengan berat badan lahir rendah (BBLR). Salah satu kelompok yang berisiko tinggi ialah ibu hamil yang mengalami anemia. Meskipun anemia yang dialami umumnya merupakan anemia akibat perubahan fisiologis tubuh selama kehamilan. Menurut kriteria anemia yang ditentukan WHO dan pedoman Kemenkes 1999, adalah sebesar $37,1 \%$ dan proporsinya hampir sama antara ibu hamil di perkotaan $(36,4 \%)$ dan pedesaan $(37,8 \%)^{3}$

Anemia merupakan keadaan ketika jumlah sel darah merah atau konsentrasi pengangkut oksigen dalam darah $(\mathrm{Hb})$ tidak mencukupi untuk kebutuhan fisiologis tubuh. Menurut WHO dan pedoman Kemenkes 1999, cut-off points anemia berbeda-beda antar kelompok umur, maupun golongan individu.

Penyebab anemia dapat

dikelompokan menjadi beberapa kategori, salah satunya ialah anemia gizi yang disebabkan oleh defisiensi dalam makanan suatu factor yang dibutuhkan untuk eritropoesis. Pembentukan sel darah merah bergantung pada pasokan adekuat bahanbahan dasar esensial, yang sebagian diantaranya tidak tersedia dalam tubuh tetapi harus disediakan melalui makanan. Salah satunya ialah anemia defisiensi besi, yang terjadi jika tidak cukup banyak besi tersedia untuk proses pembentukan hemoglobin. ${ }^{3}$ Sering dijumpai pada perempuan usia subur, disebabkan oleh kehilangan darah sewaktu menstruasi dan peningkatan kebutuhan zat besi selama kehamilan. $^{4}$

Wanita hamil rentan mengalami anemia defisiensi besi karena kebutuhan oksigen pada ibu hamil lebih tinggi sehingga memicu peningkatan produksi eritropoietin. Karena hal itu volume plasma bertambah dan sel darah merah (eritrosit) meningkat. Peningkatan volume plasma terjadi dalam proporsi yang lebih besar jika dibandingkan dengan peningkatan eritrosit sehingga menyebabkan penurunan kosentrasi dari hemoglobin akibat hemodilusi. ${ }^{5}$ Anemia dalam kehamilan dapat berakibat fatal, memiliki efek negative pada kapasitas kerja, motorik dan perkembangan mental pada bayi, anakanak, dan remaja, serta pada ibu hamil dapat menyebabkan berat lahir rendah, kelahiran premature, keguguran, partus lama, atonia uteri dan menyebabkan perdarahan serta syok (CDC, 2002).

Status ekonomi dapat berpengaruh terhadap terjadinya anemia pada kehamilan. Hasil penelitian Yanti menunjukan bahwa, kejadian anemia pada ibu hamil lebih banyak dimiliki oleh responden dengan status ekonomi rendah dibandingkan dengan responden yang status ekonomi tinggi. ${ }^{6}$ Kurangnya pendapatan menyebabkan kurangnya pemenuhan kebutuhan pangan sehari-hari sehingga berpengaruh terhadap jumlah dan kualitas makanan yang di konsumsi ibu tiap harinya berdampak pada penurunan status gizi pada ibu hamil. berbeda dari hasil penelitian Sugiarsih (2013), menunjukan bahwa tidak ada hubungan antara status ekonomi dengan kadar hemoglobin (anemia) pada ibu hamil. ${ }^{7}$ Tingkat sosial 
ekonomi diantaranya adalah pendapatan, pendidikan dan jumlah anggota keluarga. Tingkat ekonomi yang rendah dapat mempengaruhi pola makan. ${ }^{8}$ Hasil penelitian ini tidak sejalan dengan teori, karena walaupun status ekonomi keluarga rendah tetapi pengetahuan dan pendidikan responden baik, kejadian anemia pada ibu hamil tidak akan terjadi karena paham tentang makanan yang sebaiknya dikonsumsi oleh ibu selama kehamilan.

Hasil penelitian status gizi ibu hamil di wilayah kerja puskesmas tuminting kec. Tuminting kota manado sebagian memiliki rata-rata kadar hemoglobin 9,7 gr\% dengan kadar hemoglobin paling rendah $7,1 \mathrm{gr} \%$ dan paling tinggi yaitu 10,9 gr\%, ada hubungan status gizi dengan kejadian anemia pada ibu hamil di wilayah kerja puskesmas tuminting kec. Tuminting kota manado. ${ }^{9}$

Masalah gizi akan meningkatkan resiko kesakitan dan kematian bayi. Seorang ibu hamil akan melahirkan bayi yang sehat bila tingkat kesehatan dan gizinya berada pada kondisi yang baik. Namun sampai saat ini masih banyak ibu hamil yang mengalami masalah gizi khususnya gizi kurang seperti Kurang Energi Kronis (KEK) dan Anemia. Oleh karena itu, zat besi sangat dibutuhkan oleh ibu hamil untuk mencegah terjadinya anemia dan menjaga pertumbuhan janin secara optimal. Kementerian Kesehatan menganjurkan agar ibu hamil mengonsumsi paling sedikit 90 pil zat besi selama kehamilannya. $^{3}$

Anemia merupakan salah satu masalah kesehatan utama yang belum dapat diatasi. Hal ini merupakan salah satu target SDG's ketiga yaitu menjamin adanya kehidupan yang sehat, serta mendorong kesejahteraan untuk semua orang di dunia pada semua usia. Sesuai dengan point 3.1 pada tahun 2030, mengurangi angka kematian global ibu kurang dari 70 per 100.000 kelahiran. Point 3.2 Pada tahun 2030, akhir kematian dapat dicegah dari bayi yang baru lahir dan anak di bawah 5 tahun, dengan semua negara yang bertujuan untuk mengurangi angka kematian neonatal, setidaknya kurang dari 12 per 1.000 kelahiran dan di bawah-5 kematian kurang dari 25 per 1.000 kelahiran. Serta Point 3.4 Pada tahun 2030, mengurangi kematian satu dari tiga bayi prematur dari penyakit tidak menular melalui pencegahan pengobatan dan meningkatkan kesehatan mental dan kesejahteraan. ${ }^{10}$

Berdasarkan uraian diatas, penulis tertarik untuk melakukan penelitian tentang factor-faktor yang berhubungan dengan kejadian anemia pada ibu hamil di Manado. Tujuan pada penelitian ini adalah untuk mengetahui faktor-faktor apa saja yang mempengaruhi kejadian anemia pada ibu hamil.

\section{METODE PENELITIAN}

Penelitian ini merupakan penelitian analitik deskriptif dengan desain Cross sectional yang dilakukan pada bulan September-november 2016. Pengambilan sampel dilakukan di Puskesmas Ranotana.

\section{HASIL PENELITIAN}

Responden dalam penelitian ini ialah ibu hamil yang datang pada Puskesmas Ranotana Weru, Puskesmas Bahu, Puskesmas Tuminting, Puskesmas Kombos dan Puskesmas Paniki. jumlah sampel dari 5 Puskesmas yang di jadikan subjek penelitian berjumlah 49 orang ibu hamil.

Hasil penelitian ini menunjukan bahwa dari 5 puskesmas yang dilakukan penelitian terdapat sebanyak 49 ibu hamil. Sebanyak $8 \mathrm{ibu}$ hamil pada puskesmas Ranotana Weru, 7 ibu hamil pada puskesmas bahu, 1 ibu hamil pada puskesmas tuminting, 4 ibu hamil pada puskesmas kombos dan 29 ibu hamil pada puskesmas paniki. Kota Manado pada tahun 2014 berdasarkan data dari dinas kesehatan provinsi Sulawesi utara di ketahui jumlah ibu hamil sebanyak 44.358 orang sudah termasuk ibu hamil yang melakukan kunjungan antenatal care (ANC) dan juga yang mendapatkan tablet besi $(\mathrm{Fe}){ }^{11}$

Karakteristik responden penelitian tidak berdasarkan usia kehamilan, yaitu 49 orang ibu hamil. Untuk distribusi 
berdasarkan umur, responden dengan kategori umur 21-35 memiliki distribusi terbanyak, yaitu $69,4 \%$. Sedangkan distribusi berdasarkan kategori umur yang terendah adalah umur $>35$, yaitu 8,2. Selanjutnya pekerjaan suami responden lebih banyak yang memiliki suami bekerja, yaitu 91,8\%, Responden dengan suami yang berlatarbelakang tamat SMA paling banyak dalam penelitian ini, yaitu $53,8 \%$. Dan untuk latar belakang pendidikan responden yang terbanyak adalah tamat SMA, yaitu $63,3 \%$ dari total 49 orang responden sedangkan untuk responden yang terendah adalah tamat SLTP/SMP, yaitu $14,3 \%$.

Tabel 1. Karakterisitik Responden Penelitian

\begin{tabular}{lcc}
\hline \multicolumn{1}{c}{ Karakteristik } & n & \% \\
\hline Ibu Hamil & 49 & 100 \\
\hline Umur (Tahun) & & \\
$<20$ & 11 & 22,4 \\
$21-35$ & 34 & 69,4 \\
$>35$ & 4 & 8,2 \\
\hline Pekerjaan Suami : & & \\
Tidak bekerja & 4 & 8,2 \\
Bekerja & 45 & 91,8 \\
\hline Pekerjaan Istri : & & \\
Ibu Rumah Tangga & 28 & 57,1 \\
Bekerja & 21 & 42,9 \\
\hline Pendidikan Suami : & & \\
Tamat SLTP/SMP & 3 & 23 \\
Tamat SMA & 7 & 53,8 \\
Tamat Diploma & 3 & 23 \\
\hline Pendidikan Istri : & & \\
Tamat SLTP/SMP & 7 & 14,3 \\
Tamat SMA & 31 & 63,3 \\
Tamat Diploma & 11 & 22,4 \\
\hline Penghasilan Suami : & & \\
<UMP & 14 & 28,6 \\
>UMP & 35 & 71,4 \\
\hline
\end{tabular}

Tabel 2. Distribusi Responden Berdasarkan Kadar Hemoglobin (hb)

\begin{tabular}{ccc}
\hline Kadar Hemoglobin & n & \% \\
\hline $\mathrm{Hb}<11 \mathrm{~g} / \mathrm{dl}$ & 22 & 44,9 \\
$\mathrm{Hb}>11 \mathrm{~g} / \mathrm{dl}$ & 27 & 55,1 \\
Total & 49 & 100 \\
\hline
\end{tabular}

Tabel 2 menunjukkan jumlah responden yang memiliki jumlah terbanyak yaitu pada responden yang memiliki $\mathrm{hb}$ lebih dari $11 \mathrm{~g} / \mathrm{dl}$ sebanyak 27 orang $(55,1 \%)$.

Tabel 3. Hubungan Antara hb dengan Status Pekerjaan Responden

\begin{tabular}{|c|c|c|c|c|}
\hline \multirow{2}{*}{$\begin{array}{c}\text { Kadar } \\
\text { Hb }\end{array}$} & \multicolumn{2}{|c|}{ Status Bekerja } & \multirow[b]{2}{*}{ Total } & \multirow{2}{*}{$\underset{(\alpha=0,0)}{\mathbf{P}}$} \\
\hline & $\begin{array}{c}\text { IRT } \\
\mathrm{n}(\%)\end{array}$ & $\begin{array}{c}\text { Bekerja } \\
\text { n }(\%)\end{array}$ & & \\
\hline $\mathrm{Hb}<$ & 11 & 11 & 22 & \\
\hline $11 \mathrm{~g} / \mathrm{dl}$ & $(22,4 \%)$ & $(22,4 \%)$ & $(44,9 \%)$ & 0,36 \\
\hline $\mathrm{Hb}>$ & 17 & 10 & 27 & 2 \\
\hline $11 \mathrm{~g} / \mathrm{dl}$ & $(34,7 \%)$ & $(20,4 \%)$ & $(55,1 \%)$ & \\
\hline
\end{tabular}

Tabel 3 terlihat bahwa sebanyak 11 orang $(22,4 \%)$ dengan status pekerjaan bekerja dan ibu rumah tangga memiliki kadar hb kurang dari $11 \mathrm{~g} / \mathrm{dl}$. Sedangkan sebanyak 17 orang $(34,7 \%)$ dengan status pekerjaan ibu rumah tangga memiliki kadar hb lebih dari $11 \mathrm{~g} / \mathrm{dl}$ dan sebanyak 10 orang $(20,4 \%)$ dengan status pekerjaan bekerja memiliki kadar hb lebih dari $11 \mathrm{~g} / \mathrm{dl}$. Selanjutnya dengan hasil uji Chi-Square Test diperoleh taraf signifikan atau nilai $\mathrm{p}$ sebesar 0,362 yakni lebih besar dibandingkan $\alpha=0,05$. Hal ini menunjukan bahwa tidak ada hubungan bermakna antara kadar hemoglobin dengan status pekerjaan responden.

Tabel 4. Hubungan Antara hb dengan Pendidikan Responden

\begin{tabular}{lcc}
\hline \multirow{2}{*}{ Pendidikan } & \multicolumn{2}{c}{ Kadar Hemoglobin } \\
\cline { 2 - 3 } & $\mathrm{Hb}<11$ & $\mathrm{Hb}>11$ \\
$\mathrm{~g} / \mathrm{dl}$ & $\mathrm{g} / \mathrm{dl}$ \\
\hline Tamat SLTP/SMP & 4 & 3 \\
$\mathrm{n}(\%)$ & $(8,2 \%)$ & $(6,1 \%)$ \\
Tamat SLTA/SMA & 14 & 17 \\
$\mathrm{n}(\%)$ & $(28,6 \%)$ & $(34,7 \%)$ \\
Tamat Diploma & 4 & 7 \\
$\mathrm{n}(\%)$ & $(8,2 \%)$ & $(14,3 \%)$ \\
Total & $22(44,9 \%)$ & $27(55,1 \%)$ \\
\hline $\mathrm{P}^{(\alpha=0,05)}$ & \multicolumn{2}{c}{0,688}
\end{tabular}

Tabel 4 menunjukkan sebanyak 14 orang $(28,6 \%)$ pada pendidikan tamat SLTA/SMA dengan kadar hemoglobin 
kurang dari $11 \mathrm{~g} / \mathrm{dl}$ merupakan yang tertinggi sedangkan pada pendidikan tamat SLTP/SMP dan tamat Diploma dengan kadar hemoglobin kurang dari $11 \mathrm{~g} / \mathrm{dl}$ merupakan yang terendah yaitu 4 orang $(8,2 \%)$. Kadar hemoglobin lebih dari 11 $\mathrm{g} / \mathrm{dl}$ pada tingkat pendidikan tamat SLTA/SMA merupakan terbanyak yaitu 17 orang $(34,7 \%)$ sedangkan yang terendah pada tamat SLTP/SMP dengan jumlah 3 orang $(6,1 \%)$. Berdasarkan hasil analsis dengan uji Chi-Square Test diperoleh nilai p sebesar 0,688 lebih besar dibandingkan $\alpha=0,05$. Menunjukan bahwa tidak ada hubungan bermakna antara kadar hemoglobin dengan pendidikan responden.

Tabel 5 menunjukan bahwa kadar hb kurang dari $11 \mathrm{~g} / \mathrm{dl}$ dengan penghasilan kurang dari UMP sebanyak 7 orang $(14,3 \%)$ dan pada penghasilan lebih dari UMP sebanyak 15 orang $(30,6 \%)$. Sedangkan berdasarkan kadar hb lebih dari $11 \mathrm{~g} / \mathrm{dl}$ menunjukan dengan penghasilan kurang dari UMP sebanyak 7 orang $(14,3 \%)$ dan pada penghasilan lebih dari UMP didapatkan hasil sebanyak 20 orang (55,1\%). Berdasarkan hasil uji Chi-Square Test diperoleh taraf signifikan sebesar 0,650 yakni lebih besar dibandingkan $\alpha=0,05$. Menunjukan bahwa tidak ada hubungan bermakna antara kadar hemoglobin dengan penghasilan suami responden.

Tabel 5. Hubungan Kadar hb dengan Penghasilan Suami Responden

\begin{tabular}{ccccc}
\hline \multirow{2}{*}{ Kadar Hb } & \multicolumn{2}{c}{ Penghasilan } & \multirow{2}{*}{ Total } & \multirow{2}{*}{$\mathbf{P}$} \\
\cline { 2 - 3 } & $\begin{array}{c}<\text { UMP } \\
\mathrm{n}(\%)\end{array}$ & $\begin{array}{c}>\text { UMP } \\
\mathrm{n}(\%)\end{array}$ & & \\
\hline $\mathrm{Hb}<11 \mathrm{~g} / \mathrm{dl}$ & $7(14,3 \%)$ & $15(30,6 \%)$ & $22(44,9 \%)$ & \multirow{2}{*}{0,650} \\
$\mathrm{Hb}>11 \mathrm{~g} / \mathrm{dl}$ & $7(14,3 \%)$ & $20(40,8 \%)$ & $27(55,1 \%)$ & \\
\hline
\end{tabular}

\section{BAHASAN}

Hasil penelitian pada ibu hamil berumur 21-35 tahun yaitu $69,4 \%$ yang merupakan usia reproduktiv, yaitu rentang usia 15-44 tahun. Pada usia ini wanita memiliki kesempatan 95\% untuk hamil. ${ }^{12}$ Dalam reproduksi sehat dikenal bahwa usia kehamilan yang aman untuk kehamilan dan persalinan adalah 21-35 tahun. Kehamilan pada usia muda lebih beresiko dibandingkan dengan usia dalam reproduksi sehat, angka kesakitan dan angka kematian ibu dan bayi pada kehamilan remaja dua hingga empat kali lebih tinggi dibandingkan dengan kehamilan di usia 20-35 tahun. $^{13}$ Pada penelitian yang dilakukan di Southeast Ethiopia prevalensi anemia lebih tinggi $(34,6 \%)$ pada wanita hamil dalam kelompok usia 18- 26 tahun hal ini membuktikan bahwa usia juga dapat menjadi faktor resiko. ${ }^{14}$

Hasil pemeriksaan kadar hb pada ibu hamil didapatkan kadar hb kurang dari 11 $\mathrm{g} / \mathrm{dl}$ sebanyak 22 orang $(44,9 \%)$ dan responden yang memiliki hb lebih dari 11 g/dl sebanyak 27 orang $(55,1 \%)$. Hb merupakan senyawa pembawa oksigen pada sel darah merah. Hb dapat diukur secara kimia dan jumalah hb/100 ml darah dapat digunakan sebagai indeks kapasitas pembawa oksigen pada darah. Hemoglobin tersusun dari senyawa kompleks protein globin dan heme. Satu molekul hemoglobin terdiri dari empat molekul globin dan empat heme sehingga setiap satu molekul hemoglobin mempunyai empat atom besi. Struktur molekul hemoglobin ini yang dapat mengikat oksigen, dan zat besi harus berada dalam bentuk tereduksi $\left(\mathrm{Fe}^{2+}\right.$ atau ferro). Pada orang dewasa, volume darah didalam tubuh sekitar 5 liter. Setiap sel darah merah mengandung 280 juta molekul hemoglobin. Setiap detik tubuh harus memproduksi 2,5 juta sel darah merah. ${ }^{15}$ Pada kehamilan kebutuhan oksigen lebih 
tinggi sehingga memicu peningkatan produksi eritropoietin. Akibatnya volume plasma bertambah dan sel darah merah meningkat. Peningkatan volume plasma yang lebih besar dibandingkan dengan peningkatan eritrosit sehingga terjadi penurunan kosentrasi hemoglobin akibat hemodilusi. ${ }^{16}$ Anemia secara praktis didefinisikan sebagai kadar hb di bawah batas normal. Umumnya ibu hamil dianggap anemic jika kadar hemoglobin dibawah $11 \mathrm{~g} / \mathrm{dl} .{ }^{17}$

Pada hasil analisis hubungan antara kadar hemoglobin dengan status pekerjaan responden, hasil penelitian ini sesuai dengan penelitian yang dilakukan RD Aisyah bahwa $60,9 \%$ responden yang mengalami anemia memiliki status pekerjaan bekerja dan $74,2 \%$ responden yang mengalami anemia dengan status pekerjaan tidak bekerja. Dari hasil analisis di dapatkan nilai $p=0,201$ sehingga tidak terdapat hubungan yang bermakna antara kadar hb dengan pekerjaan. ${ }^{18}$

Responden yang tidak bekerja cenderung memiliki status sosial ekonomi yang lebih rendah dan mereka harus melakukan kerja keras selama kehamilan untuk mencukupi kebutuhannya. Hal ini menyebabkan kebutuhan nutrisi tidak tercukupi, jarak kelahiran pendek, perawatan antenatal yang tidak memadai. ${ }^{19}$ Ibu hamil dengan status pekerjaan tidak bekerja hanya sebagai ibu rumah tangga merupakan faktor resiko terjadinya anemia karena sebagian besar pendapatannya bergantung pada penghasilan suami untuk memenuhi kebutuhannya, sebagian ibu rumah tangga tersebut merupakan pada tingkat sosial ekonomi rendah. Anemia ditemukan pada pendapatan bulanannya rendah. $^{20}$

Menurut persatuan ahli gizi Indonesia, faktor-faktor yang mempengaruhi status gizi ibu hamil yaitu: faktor langsung, asupan konsumsi dan infeksi. Asupan pola konsumsi ini juga dapat mempengaruhi status kesehatan ibu, dimana pola konsumsi yang kurang baik dapat mempengaruhi kesehatan dan menimbulkan penyakit pada ibu. Faktor tidak langsung, pendapatan keluarga, pendapatan dapat mempengaruhi daya beli untuk membeli sesuatu. Pendapatan merupakan faktor yang paling menentukan kuantitas dan kualitas makanan dan gizi ibu selama bulan-bulan terakhir kehamilan. Oleh karena itu, pekerjaan sangat berpengaruh bagi kecukupan pemenuhan kebutuhan gizi seimbang. $^{21}$

Hasil analsis hubungan antara kadar hemoglobin dengan pendidikan responden berbeda dengan penelitian yang dilakukan dewi puspitaningrum tahun 2014 yang menunjukan bahwa ada hubungan yang bermakna antara pendidikan ibu dengan kadar anemia. Pada kelompok berpendidikan rendah pada umumnya memiliki akses pengetahuan tentang anemia yang kurang, kurang memahami akibat yang ditimbulkan dari anemia, kurang dapat memilih bahan makanan yang bergizi khususnya yang terdapat kandungan zat besi serta kurangnya pemanfaatan layanan kesehatan masyrakat yang tersedia sehingga dapat mempengaruhi kadar $h b .^{22}$ Asupan gizi merupakan faktor yang mempengaruhi anemia pada ibu hamil. Oleh karena itu asupan gizi menjadi sangat penting. Seperti penelitian yang dilakukan Abriha A bahwa prevalensi anemia pada ibu hamil secara keseluruhan yang dilakukannya adalah $19,7 \%$ dengan konsumsi daging yang sangat kurang. ${ }^{23}$

Hasil yang relatif sama juga ditunjukan dari penelitian yang dilakukan Ridayanti tahun 2013 di puskesmas banguntapal I Bantul bahwa ada hubungan yang bermakna dengan hasil penelitian sebagian besar ibu hamil berpendidikan menengah dan tidak mengalami anemia sebesar $77,2 \% .^{24}$ Tingkat pendidikan memiliki peranan yang sangat penting untuk mendapatkan pekerjaan. Tingkat pendidikan responden juga sangat mempengaruhi besarnya pendapatan responden. Semakin tinggi pendidikan seseorang maka pekerjaan dan pendapatannya semakin layak dan meningkat hal ini juga berpengaruh terhadap pendapatan dari keluarga. Jika dikaitkan dengan kesehatan, pendidikan 
dengan kesehatan memiliki pengaruh yang berkaitan.

Sesuai dengan penelitian yang dilakukan A D Putri yang meneliti pengaruh faktor pendidikan terhadap pendapatan rumah tangga bahwa pendidikan berpengaruh positif dan signifikan secara parsial terhadap pendapatan rumah tangga. ${ }^{25}$

Hubungan antara kadar hemoglobin (hb) dengan penghasilan suami berdasarkan UMP Kota Manado pada tabel 5 menunjukan bahwa tidak ada hubungan yang bermakna. Berbeda dengan penelitian yang dilakukan lokare PO di india yaitu didapatkan hasil yang signifikan secara statistik antara penghasilan dengan kadar hemoglobin. Dimana status sosial ekonomi rendah dikaitkan dengan peningkatan resiko anemia pada kehamilan. Jelas bahwa penghasilan rendah, prevalensi anemia menjadi meningkat. ${ }^{26}$

Dukungan keluarga khususnya suami memiliki efek pada kesehatan ibu karena lingkungan keluarga, pendapatan suami, pengetahuan, sikap dan praktek anggota keluarga tentang anemia pada kehamilan akan mempengaruhi perilaku ibu hamil terhadapa anemia pada kehamilan. Tingkat penghasilan suami tinggi cenderung lebih dapat memenuhi kebutuhan untuk mencukupi asupan gizi selama kehamilan. Sehingga resiko ibu hamil mengalami anemia cenderung kurang. ${ }^{27}$ Setiap manusia memiliki kebutuhan untuk menjalani kehidupan mereka. Kebutuhan pokok dibagi menjadi tiga yaitu pangan, sandang, dan papan.untuk memenuhi kebutuhan tersebut setiap manusia mencari pekerjaan untuk mendapatkan penghasilan. Sehingga penghasilan menjadi faktor utama penentu kecukupan pemenuhan asupan gizi dan kualitas hidup. Makin tinggi penghasilan makin tinggi juga taraf kehidupannya. ${ }^{28}$

\section{SIMPULAN}

Pada penelitian ini tidak terdapat hubungan antara status pekerjan dan pendidikan ibu hamil serta penghasilan suami dengan kadar hemoglobin ( $\mathrm{Hb})$ ibu hamil.

\section{DAFTAR PUSTAKA}

1. Allen, L. H, 1996. Iron- Ascorbic Acid And Iron-Calsium Interctions And Thwir Relevane In Complementary Feeding In Micronutrient Interaction: Impact On Child Health And Nutrition. Washington, DC: US Agency for International Development.

2. Almatsier, S, 2010.Ilmu Gizi Dasar. PT. Gramedia Pustaka Utama: Jakarta

3. Departemen Kesehatan Republik Indonesia. Laporan hasil riset kesehatan dasar Indonesia (Riskesdas). 2013

4. Price and Wilson. Patofisiologi konsep klinis proses-proses penyakit. Edisi ke-6. Jakarta: EGC; 2005;1. h. 260.

5. Cunninggham, Leveno, Bloom, Hauth, Rouse, \& Spong. (2013). Obstetric Williams. Jakarta: EGC.

6. Yanti DAM, Sulistianingsih A, Keisnawati. Faktor-faktor terjadinya anemia pada ibu primigravida di wilayah kerja puskesmas pringsewu lampung. Jurnal Keperawatan. 2015; 06:82.

7. Sugiarsih U, Wariyah. Hubungan tingkat sosial ekonomi dengan kadar haemoglobin. Jurnal Kesehatan Reproduksi. 2013; 04:89-90.

8. Winarno FG. Kimia Pangan Dan Gizi. 1997. Jakarta: Gramedia Pustaka Utama.

9. Marlapan S, Wantouw B, Sambeka J. Hubungan status gizi dengan kejadian anemia pada ibu hamil diwilayah kerja puskesmas tuminting kec. Tuminting kota manado.Gizi. 2013;

10. Department of Economic and Social Affairs. Sustainable Development Knowledge Platform. Sustainable Development Goals. United Nation. 2015. Available from: https://sustainabledevelopment.un.org /topics/sustainabledevelopmentgoals

11. Badan Pusat Statistik Provinsi Sulawesi Utara.Sulawesi Utara Dalam Angka 2015. 2015.

12. World Health Organization. Women health, September 2013

13. Destaria, Selvi, Pramono, B Adi. Perbandingan luaran maternal dan perinatal kehamilan trimester ketiga antara usia muda dan usia reproduksi sehat [undergraduate]. Semarang: 
Universitas Diponogoro; 2011.

14. Kefiyalew F, Zemene E, Asres Y, Gedefaw L. Anemia among pregnant women in Southeast Ethiopia: prevalence, severity and associated risk factors. Biomed central (BMC). 2014; 7(1): 771.

15. Dr. Briawan. Anemia Masalah gizi pada remaja wanita. Jakarta: EGC; 2013. h. 15-16.

16. Sarwono P. Kelainan hematologik. Abdul BS, Trijatmo R, Gulardi HW, editors. Ilmu kebidanan. Edisi keempat. Jakarta: PT Binas Pustaka Sarwono Prawirohardjo; 2014. h. 775.

17. Kefiyalew F, Zemene E, Asres $Y$, Gedefaw L. Anemia among pregnant women in Southeast Ethiopia: prevalence, severity and associated risk factors. Biomed central (BMC). 2014; 7(1): 771.

18. RD Aisyah, Fitriyani. Hubungan frekuensi ANC, dukungan suami, pekerjaan dengan kejadian anemia pada ibu hamil. kebidanan. 2016.

19. Bedi R, Acharya R, Gupta R, Pawar S, Sharma R. Maternal factors of anemia in $3^{\text {rd }}$ trimester of pregnancy and its association with fetal outcome. International multispeciality journal of health (IMJH). 2015;1:7.

20. Obay, Ondogo, Wanyama. Prevalence of anemia and associated risk factors among pregnant women attending antenatal care in gulu and hoima regional hospital in Uganda.BioMed Central Pregnancy and Childbirth. 2016; 16:76. DOI 10.1186/s12884016-0865-

21. Persatuan ahli gizi Indonesia (Persagi).
AHU-20, 2014.

22. D Puspitaningrum, NM Fratika. Hubungan pengetahuan tentang anemia, pendidikan ibu, konsumsi tablet $\mathrm{Fe}$ dengan kadar hb pada ibu hamil trimester III di RB Bhakti Ibu Kota Semarang. Nutrisi. 2014

23. Abriha A, Yusuf ME, Wassie MM. Prevalence and associated factors of anemia among pregnant women of Mekelle town: a cross sectional study. BioMed Central. 2014; 7:888.

24. NKA Ridayanti, F Lanni, M Wahyuningsih. Hubungan tingkat pendidikan ibu hamil dengan kejadian anemia padakehamilannya di puskesmas banguntapal I bantul. Media Respati. 2013; 8:1.

25. AD Putri, D Setiawina. Pengaruh Umur, Pendidikan, Pekerjaan Terhadap Pendapatan Rumah Tangga Miskin di Desa Bebandem. Ekonomi. 2013;2:173-225.

26. Lokare PO, Karanjekra VD, Gattani PL, Kulkarni Ap. A study of prevalence of anemia and sociodemographic factors associated with anemia among pregnant women in Aurangabad city, India. Annals of Nigeria medicine. 2012; 6:30-34.

27. Ahmad N, Kalakoti P, Bano R, Syed MMA. The prevalence of anemia and associated factors in pregnant women in a rural Indian community. Australasian Medical jurnal. 2011;3,5:276-280.

28. MB Setiawan dan A Hakim. Indeks pembangunan manusia Indonesia. Economic jurnal. 2013; 9:1. 